\title{
Luteal concentrations of oxytocin decline during early pregnancy in the ewe
}

\author{
E. L. Sheldrick and A. P. F. Flint \\ A.R.C. Institute of Animal Physiology, Babraham, Cambridge CB2 4AT, U.K.
}

\begin{abstract}
Summary. The concentration of oxytocin in ovine corpora lutea dropped during pregnancy from $373 \mathrm{ng} / \mathrm{g}$ wet weight on Day 14 to $<5 \mathrm{ng} / \mathrm{g}$ between Day 50 and term. The major decrease occurred before Day 20 after mating. Circulating concentrations of oxytocin also decreased between Days 10 and 15 after mating, and were low in late gestation; however, concentrations of oxytocin in plasma on Days 16 and 17 were raised. Mean luteal concentrations of oxytocin ranged from 730 to $2482 \mathrm{ng} / \mathrm{g}$ between Days 8 and 14 of the oestrous cycle in non-pregnant sheep. Secretion of oxytocin by the corpus luteum is thought to be one of the mechanisms leading to luteal regression; therefore loss of oxytocin from the corpora lutea in early gestation may contribute to their maintenance.
\end{abstract}

\section{Introduction}

Circulating concentrations of oxytocin parallel those of progesterone during the oestrous cycle in the ewe (Sheldrick \& Flint, 1981; Webb, Mitchell, Falconer \& Robinson, 1981; Schams, LahlouKassi \& Glatzel, 1982a) and the corpus luteum of the cyclic ewe contains oxytocin (Wathes \& Swann, 1982; Flint \& Sheldrick, 1982a). Active immunization against oxytocin prolongs the life of the corpus luteum (Sheldrick, Mitchell \& Flint, 1980; Schams, Prokopp \& Schmidt-Adamopoulou, $1982 \mathrm{~b}$ ) and it has been suggested that oxytocin secreted by the corpus luteum may be involved in the process of luteal regression (Flint \& Sheldrick, 1982b, 1983).

The concentration of oxytocin in corpora lutea is reduced in hysterectomized ewes, in which luteal function is prolonged beyond the normal time of luteolysis (Wiltbank \& Casida, 1956; Sheldrick \& Flint, 1983). The purpose of the present investigation was to determine whether a reduction in the concentration of oxytocin in the corpus luteum is also associated with the maintenance of luteal function in early pregnancy.

\section{Materials and Methods}

Animals. Clun Forest ewes kept in paddocks with raddle-bearing intact or vasectomized rams were checked daily for signs of oestrous behaviour.

Jugular venous concentrations of progesterone and oxytocin were measured in 9 ewes sampled daily for one oestrous cycle. Progesterone and oxytocin were also measured in samples taken during the first 20 days of pregnancy from 8 of these ewes, and 5 of these animals were also sampled daily between 8 and 32 days pre partum. Blood samples were taken by venepuncture, usually between 14:00 and 16:00 h, into heparinized tubes. Plasma was stored at $-20^{\circ} \mathrm{C}$ until assay.

Corpora lutea from 20 pregnant ewes and from 12 non-pregnant ewes between Days 8 and 14 of the oestrous cycle were extracted and processed for radioimmunoassay as previously described (Flint \& Sheldrick, 1983). 
Radioimmunoassays. Oxytocin and progesterone were measured in plasma and corpus luteum extracts by radioimmunoassay (Sheldrick et al., 1980; Sheldrick \& Flint, 1981; Flint \& Sheldrick, 1983). For oxytocin assays, sensitivity, inter- and intra-assay coefficients of variation and extraction recovery from plasma were $2.6 \mathrm{pg} /$ tube, $10.5 \%, 8.9 \%$ and $78.2 \%$. For progesterone assays these values were $14 \mathrm{pg} /$ tube, $11 \cdot 4 \%, 5 \cdot 7 \%$ and $89.2 \%$ respectively.

\section{Results}

Mean \pm s.e.m. concentration of oxytocin in 10 corpora lutea from 8 non-pregnant ewes between 8 and 12 days after an infertile mating was $1970 \pm 616 \mathrm{ng} / \mathrm{g}$ wet weight (Table 1). The level on Day

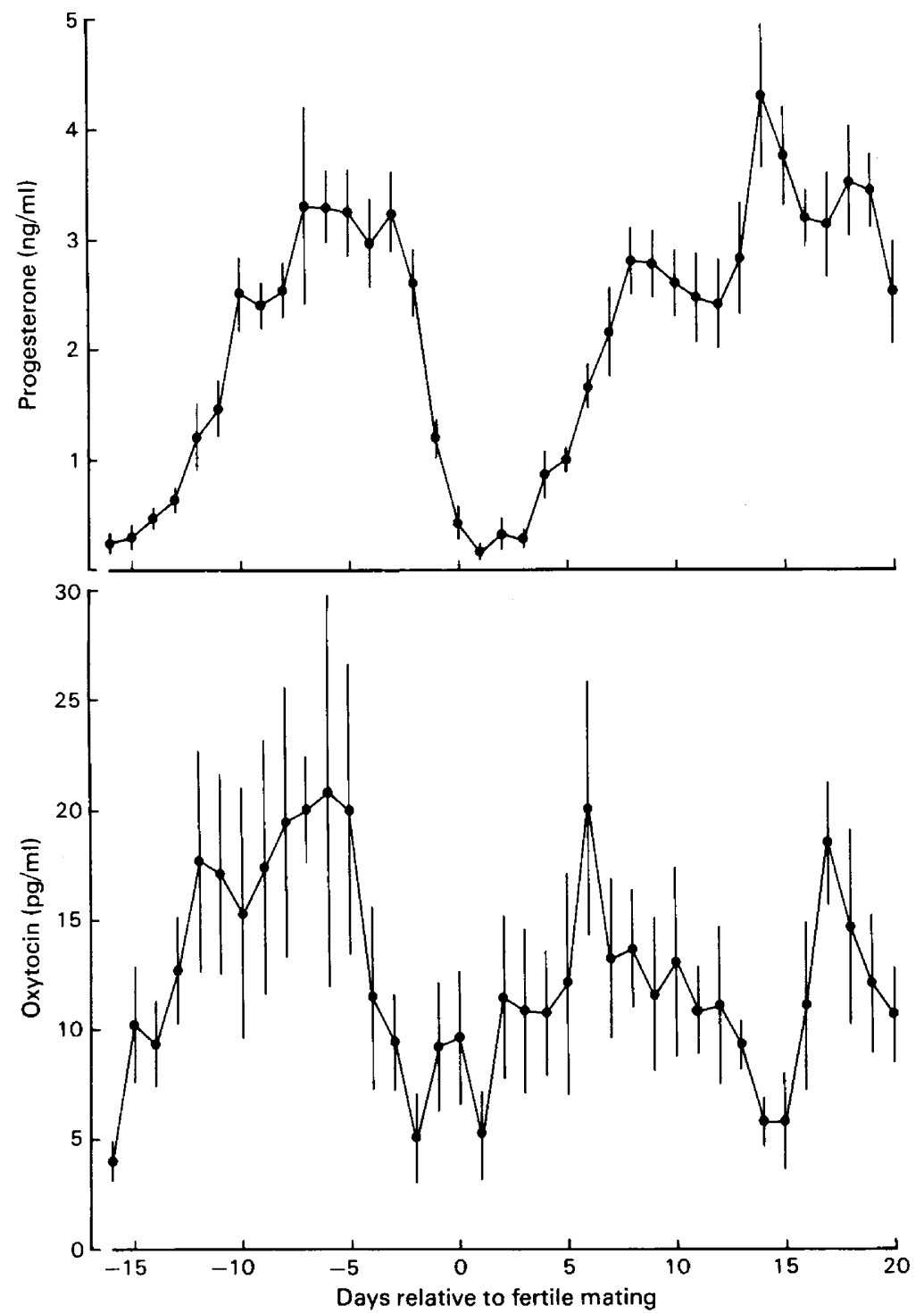

Text-fig. 1. Concentrations of oxytocin and progesterone measured in samples of jugular venous plasma obtained daily (between 14:00 and 16:00 h) from 9 sheep during one infertile oestrous cycle and in 8 of these sheep after mating to an intact ram. Values are means \pm s.e.m. All pregnant ewes delivered live lambs at normal term (145 \pm 3 days). 
Table 1. Concentrations of oxytocin measured by radioimmunoassay in acid extracts of corpora lutea

\begin{tabular}{ccccc}
\hline \multirow{2}{*}{$\begin{array}{c}\text { Day after } \\
\text { mating }\end{array}$} & Animals & Corpora lutea & $\begin{array}{c}\text { No. of } \\
\text { corpus luteum } \\
(\mathrm{mg})\end{array}$ & $\begin{array}{c}\text { Luteal oxytocin } \\
\text { conc. } \\
\text { (ng/g wet wt) }\end{array}$ \\
\cline { 2 - 3 } $\begin{array}{c}\text { Non-pregnant } \\
8\end{array}$ & 6 & & & \\
10 & 1 & 6 & $598 \pm 69$ & $2482 \pm 995$ \\
12 & 1 & 2 & $491 ; 512$ & $823 ; 914$ \\
14 & 4 & 2 & $843 ; 708$ & $1259 ; 1814$ \\
Pregnant & & 6 & $514 \pm 64$ & $730 \pm 266$ \\
14 & 4 & & & \\
15 & 1 & 6 & $694 \pm 86$ & $373 \pm 256$ \\
17 & 3 & 2 & $780 ; 400$ & $103 ; 208$ \\
20 & 1 & 4 & $830 \pm 63$ & $310 \pm 52$ \\
21 & 1 & 1 & 730 & 17 \\
30 & 1 & 2 & $726 ; 882$ & $111 ; 123$ \\
53 & 1 & 2 & $571 ; 540$ & $37 ; 31$ \\
60 & 1 & 2 & $640 ; 530$ & $3 ; 4$ \\
70 & 2 & 3 & $503 \pm 59$ & $1 \pm 0 \cdot 3$ \\
76 & 1 & 4 & $817 \pm 20$ & $4 \pm 0 \cdot 4$ \\
121 & 1 & 2 & $400 ; 870$ & $3 ; 5$ \\
133 & 1 & 2 & $590 ; 780$ & $1 ; 2$ \\
135 & 1 & 2 & $550 ; 678$ & $1 ; 2$ \\
137 & 1 & 2 & $450 ; 460$ & $1 ; 1$ \\
\hline
\end{tabular}

$14(730 \pm 266 \mathrm{ng} / \mathrm{g})$ was below this mean value $(P<0.005, t$ test). In pregnant animals, luteal oxytocin levels decreased sharply after Day 14 , and remained in the range $1-5 \mathrm{ng} / \mathrm{g}$ from Day 53 to late in gestation. It is not known whether these levels were maintained until parturition. The concentration on Day 14 of pregnancy was not significantly different from that on Day 14 of the cycle.

Circulating concentrations of oxytocin and progesterone increased with formation of the corpus luteum after non-fertile and fertile matings, as reported previously (Flint \& Sheldrick, 1983; Textfig. 1). However, peripheral plasma oxytocin levels were low on Days 14 and 15 of pregnancy, subsequently rising again on Days 16 and 17 ; the mean level on Days 14 and 15 was $5.7 \pm 1.2 \mathrm{pg} / \mathrm{ml}$ ( $n=14$ samples); on Days $7-12$ this value was $12 \cdot 2 \pm 1 \cdot 3 \mathrm{pg} / \mathrm{ml}(n=46 ; P<0.001)$, and on Days $17-20,13.9 \pm 1.9 \mathrm{pg} / \mathrm{ml}(n=28 ; P<0.001)$. In 5 ewes sampled daily between 8 and 32 days pre partum the mean peripheral plasma oxytocin concentration was $6.2 \pm 0.5 \mathrm{pg} / \mathrm{ml}(n=115$ samples). A transient rise in circulating progesterone concentration $(P<0.005)$ accompanied the reduced level of oxytocin on Days 14 and 15.

\section{Discussion}

The drop in the concentration of oxytocin in luteal tissue during pregnancy may be caused by a uterine factor or result from the process of luteal maintenance. The fact that hysterectomy leads to reduced luteal oxytocin levels does not help to differentiate between these possible mechanisms, since luteal function is also maintained after hysterectomy, as in pregnancy.

Evidence implicating luteal oxytocin secretion in the process of luteolysis includes the effect of active immunization against the peptide (Sheldrick et al., 1980; Schams et al., 1982b), the luteolytic effect of administered oxytocin which, although less marked than in the cow and goat (Armstrong \& Hansel, 1959; Cooke \& Knifton, 1981), has been reported in sheep (Milne, 1963), and the episodes of oxytocin secretion detected in sheep at luteal regression (Fairclough et al., 1980; Flint \& Sheldrick, 1983). In addition to these findings, which indicate that oxytocin may be involved in systemic mechanisms controlling luteal regression, there is evidence that gonadotrophinstimulated steroid synthesis is inhibited by neurohypophysial hormones in isolated Leydig cells and 
luteal cells in culture (Adashi \& Hsueh, 1981, 1982; Tan, Tweedale \& Biggs, 1982a, b). Therefore, in the context of local or systemic mechanisms, the loss of oxytocin from the corpus luteum in early pregnancy would be expected to lead to luteal maintenance. This is consistent with the decline in the antiluteolytic influence of the embryo between Days 16 and 21 of gestation, as indicated by failure of embryo extracts made after Day 15 to 16 to prevent luteal regression when administered into the uterus (Rowson \& Moor, 1967; Martal, Lacroix, Loudes, Saunier \& Wintenberger-Torrès, 1979). Since the time at which oxytocin disappears from the corpus luteum corresponds to the period over which embryonic antiluteolytic activity is lost, it is tempting to speculate that the loss of embryonic antiluteolysin is tolerated because of the disappearance of luteal oxytocin. The reduced susceptibility of the corpus luteum of pregnancy to administered prostaglandin (Nancarrow, Evison \& Connell, 1982) may also be a reflection of this change in the mechanisms maintaining luteal function. A decrease in luteal oxytocin, besides reducing the likelihood of luteal regression, might also be expected to reduce uterine contractility, representing a further factor contributing to the successful establishment of pregnancy.

\section{References}

Adashi, E.Y. \& Hsueh, A.J.W. (1981) Direct inhibition of testicular androgen biosynthesis revealing antigonadal activity of neurohypophysial hormones. Nature, Lond. 293, 650-652.

Adashi, E.Y. \& Hsueh, A.J.W. (1982) Direct inhibition of rat testicular androgen biosynthesis by arginine vasotocin. Studies on mechanisms of action. J. biol. Chem. 257, 1301-1308.

Armstrong, D.T. \& Hansel, W. (1959) Alteration of the bovine estrous cycle with oxytocin. J. Dairy Sci. 42, 533-542.

Cooke, R.G. \& Knifton, A. (1981) Oxytocin-induced oestrus in the goat. Theriogenology 16, 95-97.

Fairclough, R.J., Moore, L.G., McGowan, L.T., Peterson, A.J., Smith, J.F., Tervit, H.R. \& Watkins, W.B. (1980) Temporal relationships between plasma concentrations of 13,14-dihydro-15-keto prostaglandin $\mathrm{F}$ and neurophysin I/II around luteolysis in sheep. Prostaglandins 20, 199-208.

Flint, A.P.F. \& Sheldrick, E.L. (1982a) Ovarian secretion of oxytocin in the sheep. J. Physiol., Lond. 330, 61P$62 P$.

Flint, A.P.F. \& Sheldrick, E.L. (1982b) Ovarian secretion of oxytocin is stimulated by prostaglandin. Nature, Lond. 297, 587-588.

Flint, A.P.F. \& Sheldrick, E.L. (1983) Evidence for a systemic role for ovarian oxytocin in luteal regression in sheep. J. Reprod. Fert. 67, 215-225.

Martal, J., Lacroix, M.-C., Loudes, C., Saunier, M. \& Wintenberger-Torrès, S. (1979) Trophoblastin, an antiluteolytic protein present in early pregnancy in sheep. J. Reprod. Fert. 56, 63-73.

Milne, J.A. (1963) Effects of oxytocin on the oestrous cycle of the ewe. Aust. vet. J. 39, 51-52.

Nancarrow, C.D., Evison, B.M. \& Connell, P. J. (1982) Effect of embryos on luteolysis and termination of early pregnancy in sheep with cloprostenol. Biol. Reprod. 26, 263-269.

Rowson, L.E.A. \& Moor, R.M. (1967) The influence of embryonic tissue homogenate infused into the sheep uterus on the life-span of the corpus luteum. $J$. Reprod. Fert. 13, 511-516.

Schams, D., Lahlou-Kassi, A. \& Glatzel, P. (1982a) Oxytocin concentrations in peripheral blood during the oestrous cycle and after ovariectomy in two breeds of sheep with low and high fecundity. $J$. Endocr. 92, 9-13.

Schams, D., Prokopp, A. \& Schmidt-Adamopoulou, B. (1982b) The effect of active immunization against oxytocin on ovarian cyclicity in ewes. Acta endocr., Copenh., Suppl. 246, 7, Abstr.

Sheldrick, E.L. \& Flint, A.P.F. (1981) Circulating concentrations of oxytocin during the estrous cycle and early pregnancy in sheep. Prostaglandins 22, 631636.

Sheldrick, E.L. \& Flint, A.P.F. (1983) Regression of the corpora lutea in sheep in response to cloprostenol is not affected by loss of luteal oxytocin after hysterectomy. J. Reprod. Fert. 68, 155-160.

Sheldrick, E.L., Mitchell, M.D. \& Flint, A.P.F. (1980) Delayed luteal regression in ewes immunized against oxytocin. J. Reprod. Fert. 59, 37-42.

Tan, G.J.S., Tweedale, R. \& Biggs, J.S.G. (1982a) Effects of oxytocin on the bovine corpus luteum of early pregnancy. J. Reprod. Fert. 66, 75-78.

Tan, G.J.S., Tweedale, R. \& Biggs, J.S.G. (1982b) Oxytocin may play a role in the control of the human corpus luteum. J. Endocr. 95, 65-70.

Wathes, D.C. \& Swann, R. (1982) Is oxytocin an ovarian hormone? Nature, Lond. 297, 225-227.

Webb, R., Mitchell, M.D., Falconer, J. \& Robinson, J.S. (1981) Temporal relationships between peripheral plasma concentrations of oxytocin, progesterone and 13,14-dihydro-15-keto prostaglandin $F_{2 \alpha}$ during the estrous cycle and early pregnancy in the ewe. Prostaglandins 22, 443-453.

Wiltbank, J.N. \& Casida, L.E. (1956) Alteration of ovarian activity by hysterectomy. J. Anim. Sci. 15, 134-140. 